Zagazig Veterinary Journal

Volume 44, Number 2, p. 167-176, September, 2016

OFaculty of Veterinary Medicine, Zagazig University, 44511, Egypt

DOI: 10.21608/zvjz.2016.7859

\title{
Impact of Nigella sativa and Clove Oils on Cell Wall Genes Expression in Multidrug
} Resistant Staphylococcus aureus

Adel M. Attia ${ }^{1}$, Marwa I. Abd El-Hamid ${ }^{1 *}$, Mohamed E. Abd El-Reheem ${ }^{2}$ and Nehad A. Abd ElFattah $^{3}$

\author{
${ }^{1}$ Microbiology Department, Faculty of Veterinary Medicine, Zagazig University, 44511, Egypt \\ ${ }^{2}$ Virology Department, Faculty of Veterinary Medicine, Zagazig University, 44511, Egypt \\ ${ }^{3}$ Abo Hamad Hospital, Ministry of Health, Egypt
}

Article History: Received: 8/4/2016 Received in revised form: 10/9/2016 Accepted: 28/9/2016

\begin{abstract}
Antimicrobial resistance of methicillin resistant Staphylococcus aureus (MRSA) became on the top list of the serious problems that have a negative impact on public health. Therefore, this study aimed to determine the in vitro antibacterial activities of Nigella sativa ( $N$. sativa) and clove essential oils against multidrug resistant (MDR) methicillin resistant Staphylococcus aureus (MRSA) isolates recovered from different sources with a special reference to their role on the expression of penicillin binding protein $(p b p 2)$ and muscle ring finger (murF) genes. Antibiotic susceptibility testing of 51 staphylococcal isolates comprising 34 Staphylococcus aureus ( $S$. aureus) and 17 coagulase negative staphylococci (CoNs) revealed a highest sensitivity against vancomycin $(100 \%)$ and marked resistance patterns against $\beta$-lactam (beta-lactam) antibiotics. The results revealed that $97.1 \%$ of $S$. aureus isolates demonstrated a high level of MDR pattern, being resistant to more than 3 antibiotics of different classes. The in vitro antibacterial effects of clove and Nigella sativa essential oils against 11 MDR isolates using disc diffusion method indicated that both oils exhibited strong inhibitory efficiencies with inhibition zone diameters up to 45 and $20 \mathrm{~mm}$, respectively. Besides, broth microdilution test of both essential oils revealed maximum activities against the tested strains with minimum inhibitory concentrations (MICs) up to 0.5 and $8 \mu \mathrm{g} / \mathrm{mL}$ for clove and $N$. sativa oils, respectively. Quantitative RT-PCR (real time polymerase chain reaction) analysis revealed the effective role of $N$. sativa and clove oils on the down-regulation of $S$. aureus $m u r F$ and $p b p 2$ genes. In conclusion, the above findings highlight the promising antibacterial functions of $N$. sativa and clove essential oils in the treatment of emergent resistant $S$. aureus infections.
\end{abstract}

Keywords: Staphylococcus aureus, N. sativa, clove oil, microdilution, MDR.

\section{Introduction}

Staphylococcus aureus (S. aureus) is a common pathogen associated with serious community and nosocomial infections as well as being a major cause of food poisoning due to the production of enterotoxins [1].

The occurrence of $S$. aureus intoxication depends on its capability to survive and multiply under a variety of conditions in addition to the production of extracellular toxic compounds such as haemolysins, nuclease, coagulase, lipase and enterotoxins. In both human and animal medicine, methicillin resistant Staphylococcus aureus (MRSA) are among the most threatening bacteria involved in various infections [2]. Staphyloccal infections are considered public health problems worldwide. Therefore, the development of strategies to control the survival and growth of $S$. aureus is of a great interest.

Increased demand for safe and natural antimicrobials has motivated researchers to investigate the antimicrobial efficacies of many natural compounds against pathogenic microorganisms especially $S$. aureus [3]. Essential oils are complex mixtures of volatile molecules produced by the secondary metabolism of aromatic plants. Understanding the antibacterial actions of essential oils is of a great importance for their application in pharmaceutical industries. The antibacterial activities of essential oils' compounds appear 
to be due to their lipophilic nature, which allows their accumulations in biological membranes [4]. Consequently, they can disrupt the cytoplasmic membrane, increase its permeability to proteins and other cell contents and inactivate membrane-embedded enzymes $[5,6]$.

One of the most important essential oils is Nigella sativa, which has several therapeutic effects such as prevention of cancer, antiinflammatory, analgesic and antibacterial effects [7]. Most of these activities have already been attributed to thymoquinone, which is the major component of the essential oils of this seed.

Clove is another important agent which is used as a flavouring agent. The essential oils of clove have been known to posses various antibacterial and antioxidant properties due to the presence of $70-90 \%$ of their components as eugenol $[8,9]$.

The expression of high level methicillin resistance in MRSA requires not only the presence and expression of the mecA gene, but the functioning of a surprisingly large number of additional auxiliary genes including $S$. aureus penicillin binding protein ( $p b p 2)$ structural gene [10]. Moreover, the muscle ring finger $(m u r F)$ is a cell wall biosynthetic gene which is also essential for $S$. aureus in methicillin resistance [11].

It has long been known that certain cellwall targeting antibiotics can influence the expression of staphylococcal genes encoding cell wall repair enzymes, but a complete understanding of the influence of essential oils on staphylococcal cell wall genes expression is currently lacking. Therefore, owing to the prominent effects of essential oils, the present study focused on studying the antibacterial activities of $N$. sativa and clove oil against multidrug resistant MRSA isolated from different sources in addition to assessing the impact of sub-inhibitory concentrations of these oils on the expression of two cell wall biosynthesis-associated genes, $m u r \mathrm{~F}$ and $p b p 2$.

\section{Material and Methods}

\section{Clinical specimens}

One hundred and fifty-five samples were collected from animals $(n=115)$ and human $(n=40)$ sources from different areas at Sharkia Governorate, Egypt. The samples from animal origin included milk from cows showing clinical mastitis $(n=100)$ and food specimens $(n=15)$ [sausage $(n=6)$, burger $(n=4)$ and minced meat $(n=5)]$, while those from human subjects were urine $(n=7)$, pus $(n=28)$ and sputum $(n=5)$. Informed consents were obtained from all the participants in this study and it was approved by the Committee of Animal Welfare and Research Ethics, Faculty of Veterinary Medicine, Zagazig University, Egypt. The samples were transported in an ice box and microbiological examination was performed within $24 \mathrm{~h}$.

\section{Phenotypic characterization staphylococcal isolates}

Primary isolation of staphylococcal isolates was carried out onto mannitol salt agar (Oxoid, Hampshire, England, UK). Single, wellisolated colony from overnight cultures was subcultured onto blood agar for testing their beta hemolysis and milk agar for pigment production [12]. The isolates were identified by standard bacteriological methods including cultural characteristics, Gram's stain and biochemical tests such as catalase and tube coagulase tests [13].

\section{Antimicrobial resistance patterns}

Resistance of all staphyloccal isolates to various antibiotics was evaluated by disc diffusion test according to the guidelines of Clinical and Laboratory Standards Institute (CLSI) [14]. Antibacterial discs (Oxoid, Hampshire, England, UK) containing lincomycin $(2 \mu \mathrm{g})$, chloramphenicol $(30 \mu \mathrm{g})$, gentamycin $(10 \mu \mathrm{g})$, tobramycin $(10 \mu \mathrm{g})$, erythromycin $(15 \mu \mathrm{g})$, ampicillin $(10 \mu \mathrm{g})$, ciprofloxacin $(5 \mu \mathrm{g})$, amoxicillin/ clavulanic

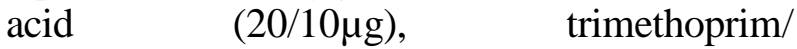
sulphamethoxazole $(1.25 / 23.75 \mu \mathrm{g})$, oxacillin $(1 \mu \mathrm{g})$, amoxicillin $(25 \mu \mathrm{g})$ and vancomycin (30 $\mu \mathrm{g})$ were used. Identification of MRSA strains was performed by molecular detection of $m e c$ A gene in oxacillin-resistant $S$. aureus isolates using PCR assay [1].

\section{Antibacterial activities of the essential oils}

Preliminary screening of the antibacterial activities of $N$. sativa (Star chemical pharmaceutical) and clove oils (MEBACO) 
was done on 11 multidrug resistant (MDR) $S$. aureus isolates with respect to their resistance patterns by the disc diffusion method as previously described [15]. It was performed using $18 \mathrm{~h}$ bacterial cultures adjusted approximately to $10^{8} \mathrm{CFU} / \mathrm{mL}$ in $10 \mathrm{~mL}$ Müller Hinton broth. The bacterial suspension was spread over the plates of Müller-Hinton agar (Oxoid, Hampshire, England, UK) using a sterile cotton swab in order to get a uniform microbial growth on both control and test plates. The used essential oils were dissolved in $10 \%$ aqueous dimethyl-sulfoxide (DMSO, Oxoid, Hampshire, England, UK)) under aseptic conditions. Empty Whatman sterile discs no. 5, $6 \mathrm{~mm}$ diameter (Oxoid, Hampshire, England, UK) were impregnated with $10 \mu \mathrm{l}$ of different concentrations $(1: 1,1: 2$, $1: 4,1: 8$ and $1: 16$ ) of the respective essential oils prepared in DMSO and were then placed on the agar surface inoculated with the bacterial culture. A sterile disc moistened with aqueous DMSO was placed on the seeded Petri-plate as a vehicle negative control. The plates were left for 30 minutes at room temperature to allow the diffusion of oils and then were incubated at $37^{\circ} \mathrm{C}$ for $24 \mathrm{~h}$. After the incubation period, the zones of inhibition around the discs were measured and recorded.

The minimum inhibitory concentrations (MIC) of $N$. sativa and clove oils were determined using the broth micro-dilution method [16]. The concentration of stock solution of the used essential oils was adjusted at $1024 \mu \mathrm{g} / \mathrm{mL}$ DMSO and the inoculum size was approximately prepared as $5 \times 10^{5}$ $\mathrm{CFU} / \mathrm{mL}$. A double fold serial dilution was made for each essential oil in custom-designed 96-well panels (Corning, New York, USA) starting from a concentration of $1024 \mu \mathrm{g} / \mathrm{mL}$. Controls of broth medium with the microorganism or the essential oil alone were included as positive and negative controls, respectively. The microplates were incubated at $37^{\circ} \mathrm{C}$ for $24 \mathrm{~h}$. The first dilution with no microbial growth was recorded as MIC of the essential oil. Subsequently, aliquots from each well were plated onto Müller Hinton agar and incubated at $37^{\circ} \mathrm{C}$ for $24 \mathrm{~h}$ to determine the MBC (minimum bactericidal concentration) of the oils. The plates were checked for growth of bacterial colonies and MBC was evaluated as the lowest oil concentration at which no growth was observed on the plates.

\section{Impact of essential oils on the expression of murF and pbp2 genes}

Eleven MDR $S$. aureus isolates grown in Müller Hinton broth were supplemented with $0.5 \times$ MIC of each of $N$. sativa and clove oils. After $24 \mathrm{~h}$ incubation, aliquots of suspended cells containing approximately $10^{8} \mathrm{CFU} / \mathrm{mL}$ were centrifuged and the supernatant was decanted and the pellet was used immediately for RNA extraction [17,18]. Total RNA extraction was accomplished according to the protocol of the QIAamp RNeasy Mini kit (Qiagen, Germany, GmbH). Quantitative RTPCR (real time polymerase chain reaction) was performed in triplicates using one-step RTPCR kit with SYBR green (Qiagen, Germany, $\mathrm{GmbH})$ in the Stratagene MX3005P real time PCR machine. The expression patterns of $m u r \mathrm{~F}$ and $p b p 2$ genes were measured by $\mathrm{qRT}-$ PCR using primers and cycling conditions detailed previously [19]. The relative quantitation of mRNA expression in each sample was normalized to the constitutive expression of the 16S rDNA housekeeping gene. The transcription levels were analyzed using the comparative $\Delta \Delta \mathrm{C}_{\mathrm{t}}$ method [20].

\section{Statistical analysis}

In order to assess the influence of $N$. sativa and clove MIC and MBC on S. aureus isolates from both human and animal sources, independent sample t-test was used following $\log _{2}$ transformation. Analysis was done using Statistical Package for Social Sciences version 22.0 (IBM Corp., Armonk, NY, USA). Results were reported in means \pm SEM (Standard Error of Mean), t-statistic and probability values. The value of $\mathrm{P}<0.05$ was used to indicate the statistical significance

\section{Results}

\section{Isolation and phenotypic characterization of Staphylococcus species}

Fifty-one staphylococci isolates (32.9\%) were recovered from 155 samples collected from different sources. Staphylococci were identified by conventional methods; all the 51 strains were Gram-positive cocci, non-motile, non-spore forming, arranged in grape-like clusters, grown onto mannitol salt agar, 
fermentative and catalase test positive, therefore, being identified as staphylococci. Among them, 34 isolates $(21.9 \%)$ were tube coagulase test positive, $\beta$-hemolytic and produced the characteristic golden yellow pigments, therefore, they were considered as coagulase positive $S$. aureus, while the other 17 isolates $(10.9 \%)$ strains were identified as coagulase negative $S$. aureus (CoNs).

Table (1): Antimicrobial susceptibility patterns of staphylococcal isolates

\begin{tabular}{lcccc}
\hline & \multicolumn{3}{c}{ Percentage of staphylococcal isolates (\%) } \\
\cline { 2 - 5 } & Antibiotic & S. aureus $(\mathbf{n}=\mathbf{3 4})$ & \multicolumn{2}{c}{ CoNs (n = 17) } \\
\cline { 2 - 5 } & $\mathbf{S}$ & $\mathbf{R}$ & $\mathbf{S}$ & $\mathbf{R}$ \\
\hline Vancomycin & 100 & 0 & 100 & 0 \\
Sulphamethoxazol/trimethoprim & 88.2 & 11.8 & 76.5 & 23.5 \\
Chloramphenicol & 76.5 & 23.5 & 76.5 & 23.5 \\
Ciprofloxacin & 67.6 & 32.4 & 100 & 0 \\
Amocillin/clavulanic acid & 50 & 50 & 82.4 & 17.6 \\
Gentamicin & 47.1 & 52.9 & 88.2 & 11.8 \\
Tobramycin & 26.5 & 73.5 & 88.2 & 11.8 \\
Erythromycin & 23.5 & 76.5 & 52.9 & 47.1 \\
Oxacillin & 2.9 & 97.1 & 5.9 & 94.1 \\
Ampicillin & 2.9 & 97.1 & 17.6 & 82.4 \\
Amoxicillin & 2.9 & 97.1 & 23.5 & 76.5 \\
Lincomycin & 2.9 & 97.1 & 0 & 100 \\
\hline
\end{tabular}

CoNs: coagulase negative staphylococci , S: Sensitive, R: resistant

\section{Antimicrobial resistance patterns}

The in vitro antimicrobial resistance profiles of all staphylococci isolates are summarized in Table (1). Antibiogram analysis revealed that the highest sensitivities of $S$. aureus were reported against vancomycin (100\%), followed by Sulphamethoxazol/ trimethoprim $(88.2 \%)$ and chloramphenicol $(76.5 \%)$, while the highest rates of resistance were observed against $\beta$-lactam antibiotics and lincomycin (97.1\%). All 33 isolates (97.1\%) which appeared oxacillin resistant phenotypically with antimicrobial susceptibility test were positive for the presence of mecA gene and were therefore confirmed as MRSA strains.

Concerning the CoNs, vancomycin and ciprofloxacin showed the maximum overall sensitivity rates against the isolates $(100 \%$, each), followed by gentamycin and tobramycin (88.2\%, each). On the other hand, high levels of resistance were recorded for lincomycin $(100 \%)$, followed by oxacillin $(94.1 \%)$.

As apparent from Table (2), the majority of $S$. aureus strains $(\mathrm{n}=33,97.1 \%)$ demonstrated multidrug resistance (MDR) pattern to 3 or more antibiotics of different classes. Additionally, $88.2 \%$ of CoNs showed the MDR pattern.

Table (2): Resistance percentages of staphylococcal isolates to one or more antimicrobials

\begin{tabular}{ccc}
\hline \multirow{2}{*}{ No. of antibiotics } & \multicolumn{2}{c}{ Percentage of staphylococcal isolates $(\%)$} \\
\cline { 2 - 3 } & S. aureus $(\mathbf{n}=\mathbf{3 4})$ & CoNs $(\mathbf{n}=\mathbf{1 7})$ \\
\hline $\mathbf{1}$ & 0 & 0 \\
$\mathbf{3}$ & 2.9 & 11.8 \\
$\mathbf{4}$ & 2.9 & 11.8 \\
$\mathbf{5}$ & 5.9 & 11.8 \\
$\mathbf{6}$ & 14.7 & 11.8 \\
$\mathbf{7}$ & 17.6 & 11.8 \\
$\mathbf{8}$ & 8.8 & 5.9 \\
$\mathbf{9}$ & 20.6 & 5.9 \\
$\mathbf{1 0}$ & 17.6 & 0 \\
\hline
\end{tabular}

CoNs: coagulase negative staphylococci 


\section{Antimicrobial activities of $N$. sativa and clove essential oils}

Preliminary screening of antibacterial activities of $N$. sativa and clove essential oils against $11 \mathrm{MDR}$ isolates was carried out by disc diffusion method. The growth inhibition zone diameters of the tested MRSA isolates are presented in Table (3). It was indicated that the concentrations of the essential oils were directly proportional to their inhibitory activities. There was no inhibition of $S$. aureus growth with vehicle control (DMSO). Concerning the antibacterial activities of the investigated essential oils, it was demonstrated that clove oil, followed by $N$. sativa essential oils showed high antibacterial activities against the tested isolates with inhibition zones diameters ranged from 9 to $45 \mathrm{~mm}$ and 1 to 20 $\mathrm{mm}$, respectively.

Table (3): Inhibition zone diameters ( $\mathrm{mm}$ ) of different concentrations of $N$. sativa and clove essential oils against 11 MDR $S$. aureus

\begin{tabular}{cccccccc}
\hline \multirow{2}{*}{$\begin{array}{c}\text { S. aureus isolate } \\
\text { code No. }\end{array}$} & \multicolumn{7}{c}{ Inhibition zone diameters (mm) } \\
\cline { 2 - 7 } & $1: 1$ & $1: 2$ & $1: 1$ & $1: 2$ & $1: 4$ & $1: 8$ & $1: 16$ \\
\cline { 2 - 7 } & 16 & 12 & 20 & 16 & 12 & 9 & - \\
\hline $\mathbf{4 5} \mathbf{S g}$ & 17 & 11 & 32 & 28 & 22 & 15 & - \\
$\mathbf{1 5} \mathbf{M}$ & 13 & 9 & 40 & 34 & 25 & 20 & - \\
$\mathbf{1} \mathbf{M}$ & 18 & 13 & 45 & 35 & 27 & 21 & 10 \\
$\mathbf{1 3} \mathbf{M}$ & 20 & 16 & 35 & 30 & 22 & 17 & 10 \\
$\mathbf{4 0} \mathbf{~ U}$ & 13 & 9 & 30 & 28 & 20 & 18 & - \\
$\mathbf{5 9} \mathbf{P s}$ & 18 & 11 & 40 & 30 & 24 & 21 & 17 \\
$\mathbf{5 8} \mathbf{P s}$ & 16 & 1 & 35 & 29 & 20 & 14 & - \\
$\mathbf{6 0} \mathbf{P s}$ & 15 & 8 & 25 & 16 & 12 & 10 & - \\
$\mathbf{5 5} \mathbf{P s}$ & 16 & 12 & 26 & 21 & 18 & 13 & - \\
$\mathbf{5 7} \mathbf{P s}$ & 15 & 10 & 25 & 15 & 12 & 9 & - \\
$\mathbf{6 1} \mathbf{P s}$ & &
\end{tabular}

Sg: Sausage, M: Milk, U: Urine, Ps: Pus, -: Resistant

Referring to the large inhibition zones observed with disc diffusion assay for $N$. sativa and clove essential oils, the MIC and MBC values for these compounds were determined with broth microdilution assays and their results were reliable with the diameters of inhibition zones observed with disc diffusion method. The results confirmed the antimicrobial activities of $N$. sativa and clove oils with higher MIC values for clove (up to $0.5 \mu \mathrm{g} / \mathrm{mL}$ ), followed by $N$. sativa oils (up to $8 \mu \mathrm{g} / \mathrm{mL}$ ) (Table 4). Statistical results showed that both $N$. sativa and clove extracts had significant inhibitory and bactericidal effects $(\mathrm{P}<0.05)$ against all studied $S$. aureus isolates from both human and animal sources.

Table (4): Minimum inhibitory and bactericidal concentrations ( $\mu \mathrm{g} / \mathrm{mL})$ of $N$. sativa and clove essential oils against $S$. aureus isolates

\begin{tabular}{|c|c|c|c|c|}
\hline \multirow{2}{*}{$\begin{array}{l}\text { S. aureus isolate } \\
\text { code No. }\end{array}$} & \multicolumn{2}{|c|}{ N. sativa $(\mu \mathrm{g} / \mathrm{mL})$} & \multicolumn{2}{|c|}{ Clove oil $(\mu \mathrm{g} / \mathrm{mL})$} \\
\hline & MIC & MBC & MIC & MBC \\
\hline $45 \mathrm{Sg}$ & 64 & 128 & 32 & 64 \\
\hline $15 \mathrm{M}$ & 16 & 32 & 1 & 2 \\
\hline $1 \mathrm{M}$ & 64 & 128 & 0.5 & 1 \\
\hline $13 \mathrm{M}$ & 32 & 64 & 0.1 & 0.25 \\
\hline $40 \mathrm{U}$ & 8 & 16 & 1 & 2 \\
\hline 59 Ps & 64 & 128 & 1 & 2 \\
\hline 58 Ps & 16 & 32 & 0.5 & 1 \\
\hline 60 Ps & 32 & 64 & 0.5 & 1 \\
\hline 55 Ps & 32 & 64 & 4 & 8 \\
\hline 57 Ps & 32 & 64 & 2 & 4 \\
\hline 61 Ps & 16 & 32 & 4 & 8 \\
\hline
\end{tabular}

Sg: Sausage, M: Milk, U: Urine, Ps: Pus, MIC: Minimum inhibitory concentration, MBC: Minimum bactericidal concentration 


\section{Regulation of murF and pbp2 genes expression}

The effects of sub inhibitory concentrations of $N$. sativa and clove essential oils on the transcriptional modulation of cell wall biosynthesis genes ( $p b p 2$ and murF) of $S$. aureus were assessed by quantitative RT-PCR. Both tested virulence genes were constitutively expressed in all isolates with different expression patterns indicating various responses. Relative expressions (fold-change or fold-difference of expression levels) of the representative genes were compared to those within the control untreated isolates, which are assigned a value of 1 .

The results showed that both tested genes were found to be down regulated after exposure to $0.5 \mathrm{x}$ MIC of $N$. sativa and clove essential oils (Table 5). The lowest mRNA expression levels were ubiquitously detected in the isolates exposed to clove oil, where the transcriptional levels of $p b p 2$ and $m u r F$ genes were remarkably decreased up to 0.2952-and 0.3186 -fold, respectively. Likewise, the use of $N$. sativa oil also repressed the expression levels of the $p b p 2$ and murF genes up to 0.4293 - and 0.5987-fold, respectively.

Table (5): Relative expression of $p b p 2$ and murF of $S$. aureus after treatment with sub-MIC of $N$. sativa and clove essential oils

\begin{tabular}{|c|c|c|c|c|}
\hline \multirow{3}{*}{$\begin{array}{c}\text { S. aureus isolate } \\
\text { code No. }\end{array}$} & \multicolumn{4}{|c|}{ Relative expression $^{a}$} \\
\hline & \multicolumn{2}{|c|}{ pbp2 } & \multicolumn{2}{|c|}{ murF } \\
\hline & $\begin{array}{l}\text { N. sativa } \\
\text { sub-MIC }\end{array}$ & $\begin{array}{l}\text { clove sub- } \\
\text { MIC }\end{array}$ & $\begin{array}{l}\text { N. sativa } \\
\text { sub-MIC }\end{array}$ & clove sub-MIC \\
\hline $45 \mathrm{Sg}$ & ND & 0.9539 & ND & 0.5664 \\
\hline $15 \mathrm{M}$ & 0.4293 & 0.9659 & 0.8526 & 0.9596 \\
\hline $1 \mathrm{M}$ & ND & 0.7900 & ND & 0.9138 \\
\hline $13 \mathrm{M}$ & ND & 0.7320 & ND & 0.8526 \\
\hline $40 \mathrm{U}$ & 0.4475 & 0.3686 & 0.5987 & 0.3186 \\
\hline 59 Ps & ND & 0.7371 & ND & 0.8586 \\
\hline 58 Ps & 0.9931 & 0.5285 & 0.9931 & 0.5285 \\
\hline 60 Ps & ND & 0.9593 & ND & 0.8706 \\
\hline 55 Ps & ND & 0.2952 & ND & 0.7900 \\
\hline 57 Ps & ND & 0.7371 & ND & 0.9302 \\
\hline 61 Ps & 0.6417 & 0.7792 & 0.8527 & 0.9202 \\
\hline
\end{tabular}

Sg: Sausage, M: Milk, U: Urine, Ps: Pus, pbp2: Penicillin binding protein, murF: Muscle ring finger, ND: Not done

${ }^{a}$ Values represent the fold change in comparison with the transcription level of the control untreated isolates, which is assigned a value of 1.0

\section{Discussion}

There is a growing concern about the rapid rise in the resistance of $S$. aureus to antimicrobial agents [21]. Therefore, the present study aimed to detect the antibacterial activities of $N$. sativa and clove oils against a group of MDR $S$. aureus isolates from different sources.

Methicillin resistant $S$. aureus are prevalent worldwide and are an important cause of nosocomial infections, resulting in increased morbidity and mortality in the hospital settings [22]. Knowledge of the pattern of antibiotic resistance among $S$. aureus isolates is very important both chemically and epidemiologically [23]. Analyzing the antibiogram results of $S$. aureus herein revealed that vancomycin showed a maximum overall sensitivity against all the tested isolates $(100 \%)$ as was recorded in a previous report in India [24]. These findings confirm that vancomycin remains the drug of choice in the treatment of infections caused by organisms resistant to $\beta$-lactame antibiotics [25]. Another observation in the present study was the maximum resistance rates of all the tested isolates against $\beta$-lactam antibiotics. A similar trend in the level of $\beta$-lactam resistance was reported in Ethiopia [26]. The majority of $S$. aureus isolates in the present study were MDR $(97.1 \%)$. This high prevalence corroborated an earlier study in India [27]. 
Molecular confirmation of oxacillin resistance showed the amplification of mecA gene in $33(97.1 \%)$ of the MDR isolates confirming them as MRSA. This was however higher than the studies conducted in Ilorin, Nigeria $(34.7 \%)$ [28], France (6\%), Ireland (5\%) and United Kingdom (2\%) [29]. However, a high prevalence rate of MRSA $(83 \%)$ was reported in Pakistan [30]. This confirms the high regional variations in the findings from different countries and cities.

Medicinal plants are considered rich sources of antimicrobial agents [31]. N. sativa has gained a special interest as a medicinal plant and there has been several reports dealing with the antimicrobial activities of its crude extract and some of its constituents [32]. In this study, $N$. sativa essential oil showed a marked inhibitory activity against MRSA tested as was previously observed [33].

Clove oil is known to be used as an alternative to conventional antibiotic therapy due to its antibacterial activity [34]. Cloves are strongly pungent due to their high content of euganol, which is known to inhibit growth of Gram-positive and negative bacteria [30]. Herein, clove oil showed higher antibacterial activities against tested MRSA. These results are in harmony with those of another study conducted in Australia, where clove essential oil exhibited a great antibacterial effect against a large number of MRSA isolates [35].

The present results indicated that $m u r \mathrm{~F}$ and $p b p 2$ transcriptions were strongly suppressed with a down regulation when $S$. aureus exposed to $0.5 \mathrm{x}$ MICs of both $N$. sativa and clove oils. The results presented here verified other observations indicating that other plant extracts at sub-inhibitory concentrations induced a cell wall stress response in $S$. aureus that is modulated by the two-component VraSR system, which in turn enhances the transcription of genes encoding cell wall repair enzymes [19]. Nevertheless, the mechanisms by which $S$. aureus regulates virulence gene expression are extremely complicated and need further molecular investigations.

\section{Conclusion}

In conclusion, $N$. sativa and clove essential oils showed maximum antibacterial activities against MDR MRSA isolates with effective roles on the down-regulation of $m u r F$ and $p b p 2$ genes. The above property could be exploited in developing these oils as antipathogenic agents against drug resistant and pathogenic $S$. aureus.

Conflict of interest: All the authors have no conflict of interest to declare.

\section{References}

[1] Pereira, V.; Lopes, C.; Castro, A.; Silva, J.; Gibbs, P. and Teixeira, P. (2009): Characterization for enterotoxin production, virulence factors, and antibiotic susceptibility of Staphylococcus aureus isolates from various foods in Portugal. Food Microbiol, 26 (3): 278-282.

[2] 2. Shale, K.; Lues, J.F.R.; Venter, P. and Buys, E.M. (2005): The distribution of Staphylococcus sp. on bovine meat from abattoir deboning rooms. Food Microbiol, 22 (5):433-438

[3] de Barros, J.C.; Conceiçáo, M.L.; GomesNeto, N.J.; Costa A.C.V.; Siqueira J.P.; Basilio, I.D. and Souza, E.L. (2009): Interference of Origanum vulgare L. essential oil on the growth and some physiological characteristics of Staphylococcus aureus strains isolated from foods. LWT-Food Sci Technol, 42: 1139-1143.

[4] Sikkema, J.; de Bont, J.A. and Poolman, B. (1994): Interactions of cyclic hydrocarbons with biological membranes. J Biol Chem, 269 (11): 8022-8028.

[5] Ultee, A.; Bennik, M.H.J. and Moezelaar, R. (2002): The phenolic hydroxyl group of carvacrol is essential for action against the food-borne pathogen Bacillus cereus. Appl Environ Microbiol, 68 (4): 1561-1568.

[6] Cristani, M.; D’Arrigo, M.; Mandalari, G.; Castelli, F.; Sarpietro, M.G.; Micieli, D.; Venuti, V.; Bisignano, G.; Saija, A. and Trombetta, D. (2007): Interaction of four monoterpenes contained in essential oils with model membranes: implications for their antibacterial activity. J Agric Food Chem, 55 (15): 6300-6308.

[7] Abdel-Fattah, A.M.; Matsumoto, K. and Watanabe, H. (2000): Antinociceptive effects of Nigella sativa oil and its major 
component, thymoquinone, in mice. Eur $\mathrm{J}$ Pharmacol, 400 (1): 89-97.

[8] Chaieb, K.; Hajlaoui, H.; Zmantar, T.; Kahla-Nakbi, A.B.; Rouabhia, M.; Mahdouani, K. and Bakhrouf, A. (2007): The chemical composition and biological activity of clove essential oil, Eugenia caryophyllata (Syzigium aromaticum L. Myrtaceae): a short review. Phytother Res, 21 (6): 501-506.

[9] Ayoola, G.A.; Lawore, F.M.; Adelowotan, T.; Aibinu, I.E.; Adenipekun, E.; Cokerb, H.A.B and Odugbemi, T.O. (2008): Chemical analysis and antimicrobial activity of the essential oil of Syzigium aromaticum (clove). Afr J Microbiol Res, 2 (7): 162-166.

[10] Chambers HF (1997): Methicillin resistance in staphylococci: molecular and biochemical basis and clinical implications. Clin Microbiol Rev, 10 (4):781-791.

[11] Sobral RG, Ludovice AM, Gardete S, Tabei K, De Lencastre H, Tomasz A. (2003): Normally functioning murF is essential for the optimal expression of methicillin resistance in Staphylococcus aureus. Microb Drug Resist, 9 (3):231241.

[12] Skalka, B.; Smola, J. and Pillich, J. (1979): Simple method of detecting staphylococcal hemolysins. Zentralbl Bakteriol Orig A, 245(3): 283-286.

[13] Bannerman, T.L.; Peacock, S.J.; Murray, P.R.; Baron, E.J.; Jorgensen, J.H.; Landry, M.L. and Pfaller, M.A. (2006): Staphylococcus, micrococcus, and other catalase-positive cocci. Manual of clinical microbiology: Volume 1, (Ed. 9), pp.390411.

[14] Clinical and Laboratory Standards Institute (CLSI) (2014): Performance standards for antimicrobial susceptibility testing; twenty-fourth informational supplement, CLSI document M100-S24, Wayne, Pennsylvania, USA, 34:134-136.

[15] Kon, K. and Rai, M. (2012): Antibacterial activity of Thymus vulgaris essential oil alone and in combination with other essential oils. Nusantara Biosciences, 4 (2):50-56.

[16] Jorgensen, J.H. and Tumidge, J.D. (2003): Susceptibility Test Methods: Dilution and Disk Diffusion Methods. In: Murray, P.R.; Boron, E.J.; Jorgensen, J.H.;Pfaller, M.A. and Yolken, R.H.editors. Manual of Clinical Microbiology. $4^{\text {th }}$ edition. Washington, DC: American Society for Microbiology. p.1008-1127.

[17] Choi N.Y., Kang S.Y., Kim K.J. (2015): Artemisia princeps inhibits biofilm formation and virulence-factor expression of antibiotic-resistant bacteria. Biomed Res Int, 2015: 239519.

[18] You, Y.O.; Choi, N.Y., Kang, S.Y. and Kim, K.J. (2013): Antibacterial activity of Rhus javanica against methicillin-resistant Staphylococcus aureus. Evid Based Complementary Altern Med, 2013: 8 pages.

[19] Levinger, O.; Bikels-Goshen, T.; Landau, E.; Fichman, M. and Shapira, R. (2012): Epigallocatechin gallate induces up regulation of the two-component VraSR system by evoking a cell wall stress response in Staphylococcus aureus. Appl Environ Microbiol, 78(22):7954-7959.

[20] Livak, K.J. and Schmittgen, T.D. (2001): Analysis of relative gene expression data using real-time quantitative PCR and the $2^{-\Delta \Delta C t}$ Method. Methods, 25: 402-408.

[21] Mulla, S.; Patel, M.; Shah L. and Vaghela, G. (2007): Study of antibiotic sensitivity pattern of methicillin-resistant Staphylococcus aureus. Indian J Critical Care Medicine, 11 (2): 99-101.

[22] Cosgrove, S.E.; Sakoulas, G.; Perencevich, E.N.; Schwaber, M.J.; Karchmer, A.W. and Carmeli, Y. (2003): Comparison of mortality associated with methicillin-resistant and methicillinsusceptible Staphylococcus aureus bacteremia: a meta-analysis. Clin Infect Dis, 36 (1):53-59.

[23] Dar, J.A.; Thoker, M.A.; Khan, J.A.; Ali, A.; Khan, M.A.; Rizwan, M.; Bhat, 
K.H.; Dar, M.J.; Ahmed, N. and Ahmad, S. (2006): Molecular epidemiology of clinical and carrier strains of methicillin resistant Staphylococcus aureus (MRSA) in the hospital settings of north India. Ann Clin Microbiol Antimicrob, 5:22.

[24] Kumar, S.; Joseph, N.; Easow, J.; Singh, R.; Umadevi, S.; Pramodhini, S.; Sirrangaraj, S. and Kumari, G. (2012): Prevalence and current antibiogram of staphylococci isolated from various clinical specimens in a tertiary care hospital in Pondicherry. Internet $\mathbf{J}$ Microbiol, 10 (1):1937-8289.

[25] Crandon, J.L.; Kuti, J.L. and Nicolau, D.P. (2010): Comparative efficacies of human simulated exposures of telavancin and vancomycin against methicillinresistant Staphylococcus aureus with a range of vancomycin MICs in a murine pneumonia model. Antimicrob Agents Chemother, 54 (12): 5115-5119.

[26] Daka, D.; Silassie, S. and Yihdego D. (2012):

Antibiotic-resistance Staphylococcus aureus isolated from cow's milk in the Hawassa area, South Ethiopia. Ann Clin Microbiol Antimicrob, 17:11-26.

[27] Tahnkiwale, S.S.; Roy, S. and Jalgaonkar, S.V. (2002): Methicillin resistance among isolates of Staphylococcus aureus: Antibiotic sensitivity pattern \& phage typing. Indian J Med Sci, 56 (7): 330-334.

[28] Taiwo, S.S.; Bamidele, M.; Omonigbehin, E.A.; Akinsinde, K.A.; Smith, S.I.; Onile, B.A. and Olowe, A.O. (2005): Molecular epidemiology of methicillin resistant Staphylococcus aureus in Ilorin, Nigeria. West Afr J Med, 24 (2):100-106.

[29] Denton, M.; O'Connell, B.; Bernard, P.; Jarlier, V.; Wiliams, Z. and Henriksen, A.S. (2008): The EPISA Study: antimicrobial susceptibility of Staphylococcus aureus causing primary or secondary skin and soft tissue infections in the community in France, the UK and Ireland. J Antimicrob Chemother, 61 (3):586-588.

[30] Mehta, A.; Rodriguez, C.; Sheath, K.; Jani, S.; Hakimiyan, A. and Fazalbhoy, N. (1998): Control of methicillin resistant Staphylococcus aureus in a tertiary care Centre-A five year study. Indian $\mathbf{J}$ Med Microbial, 16(1): 31-34.

[31] Jazani, N.H.; Zartoshti, M.; Babazadeh, H. and Ali-daiee, N. (2011): Antibacterial effects of Artemisia dracunculus essential oil on multi-drug resistant isolates of Acinetobacterbaumannii. Bacteriol J, 1: 31-36.

[32] Salem, E.M.; Yar, T.; Bamosa, A.O.; Al-Quorain A.; Yasawy M.I.; Alsulaiman, R.M. and Randhawa, M.A. (2010): Comparative study of Nigella Sativa and triple therapy in eradication of Helicobacter Pylori in patients with nonulcer dyspepsia. Saudi J Gastroenterol, 16 (3): 207-214.

[33] Karib, D.J. and Mawlood, S.I. (2001): Antimicrobial effect of Nigella sativa on Staphylococcus aureus. J Zanko, 31 (1): 37-41.

[34] Ali, H.S, Kamal, M. and Mohamed, S.B. (2009): In vitro clove oil activity against periodontal bacteria. Journal of Science and Technology, 10(1):1-7

[35] Hoque, M.M.; Bari, K.L.; Juneja, V.K. and Kawamoto, S. (2008): Antimicrobial activity of cloves and cinnamon extracts against food borne pathogens and spoilage bacteria and inactivation of Listeria monocytogenes in ground chicken meat with their essential oils. Rep Natl Food Res Inst, 72: 9-21. 


\section{الملخص العربي}

\section{تأثير زيوت حبة البركة والقرنفل على تعبير جينات الجدار الخلوى للمكورات العنقودية الذهبية المتعددة

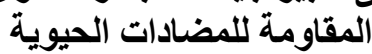

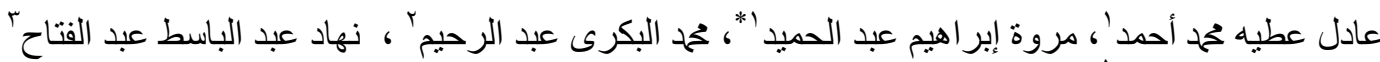

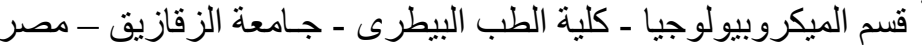

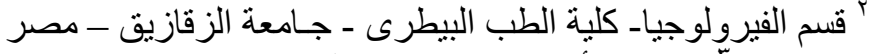

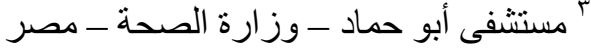

لقد أصبحت المقاومة الميكروبية للمكور العنقودى الذهبى المقاوم للميثيسيلين على قمة المشاكل الخطبرة المهددة للصحة

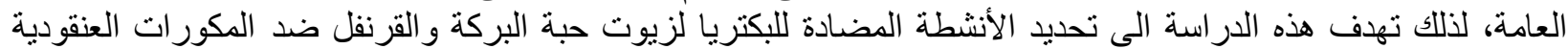

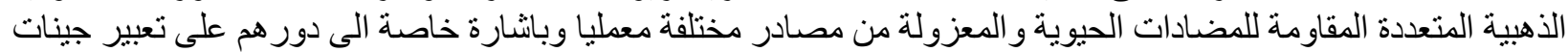
murF

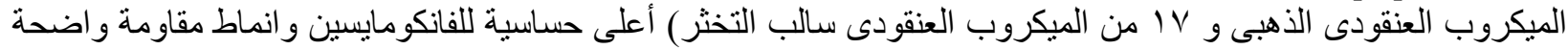

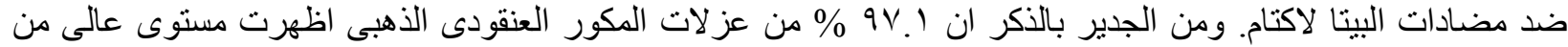

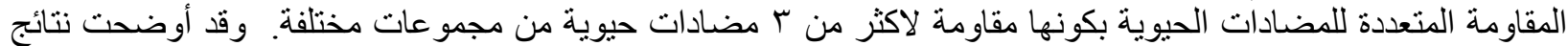

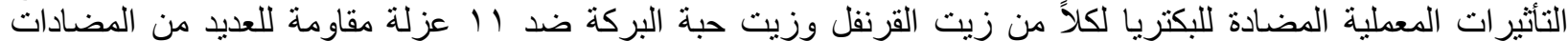

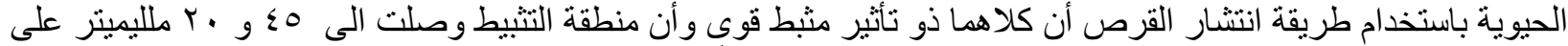

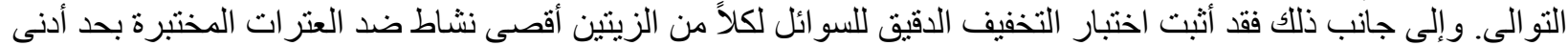

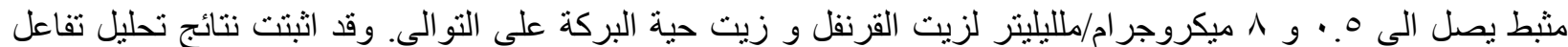

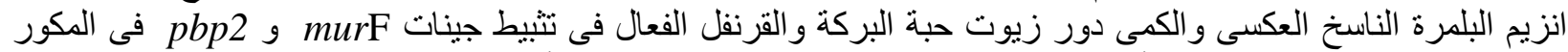

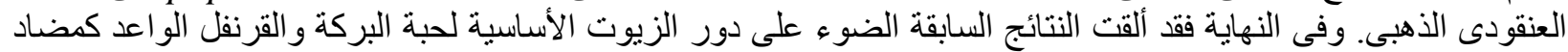

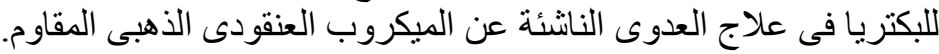

